University of Wollongong

Research Online

Faculty of Social Sciences - Papers (Archive) Faculty of Arts, Social Sciences \& Humanities

$1-1-2019$

The transition experiences of students with disabilities moving from

primary to secondary schools in NSW, Australia

Frank Pitt

University of Wollongong

Roselyn M. Dixon

University of Wollongong, roselyn@uow.edu.au

Wilma Vialle

University of Wollongong, wvialle@uow.edu.au

Follow this and additional works at: https://ro.uow.edu.au/sspapers

Part of the Education Commons, and the Social and Behavioral Sciences Commons

Research Online is the open access institutional repository for the University of Wollongong. For further information contact the UOW Library: research-pubs@uow.edu.au 


\title{
The transition experiences of students with disabilities moving from primary to secondary schools in NSW, Australia
}

\author{
Abstract \\ This paper investigates the transition experiences of students with intellectual disability, as they move \\ from primary to secondary school in New South Wales, Australia. Employing a multiple case study \\ approach, the authors investigated the transition from the perspective of the students experiencing it. \\ During the study, ten students with mild to moderate intellectual disability participated in interviews and \\ were observed in the school environment before and after they transitioned from primary school to \\ secondary school. Results indicate that students with intellectual disability generally have a positive \\ transition experience. Nevertheless, students commonly encounter a number of major challenges, \\ including issues around managing school work and homework, and bullying. The study found several \\ factors contribute to a successful transition. These include the provision of assistance to help students \\ become familiar with and manage their physical environment, building positive relationships with \\ teachers, and having extra support from special needs staff. The study suggests there are some simple \\ and practical steps that schools can take to enhance outcomes for successful transition experiences.

\section{Disciplines} \\ Education | Social and Behavioral Sciences

\section{Publication Details} \\ Pitt, F., Dixon, R. \& Vialle, W. (2019). The transition experiences of students with disabilities moving from \\ primary to secondary schools in NSW, Australia. International Journal of Inclusive Education, Online First \\ 1-16.
}




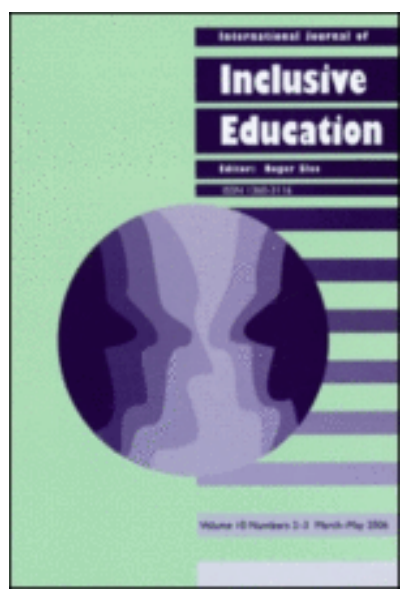

\section{The Transition Experiences of Students with Disabilities Moving from Primary to Secondary Schools in NSW, Australia}

\begin{tabular}{|r|l|}
\hline Journal: & International Journal of Inclusive Education \\
\hline Manuscript ID & TIED-2018-0250.R1 \\
\hline Manuscript Type: & Original Article \\
\hline Keywords: & $\begin{array}{l}\text { transition, Intellectual Disability, Secondary School, Transition, Autism } \\
\text { Spectrum Disorders, Case Study }\end{array}$ \\
\hline
\end{tabular}

\section{SCHOLARONE ${ }^{\text {IM }}$ \\ Manuscripts}




\title{
The Transition Experiences of Students with Disabilities Moving from Primary to Secondary Schools in NSW, Australia
}

\begin{abstract}
This paper investigates the transition experiences of students with intellectual disability, as they move from primary to secondary school in New South Wales, Australia. Employing a multiple case study approach, the authors investigated transition from the perspective of the students experiencing it. During the study, ten students with mild to moderate intellectual disability participated in interviews and were observed in the school environment before and after they transitioned from primary school to secondary school. Results indicate that students with intellectual disability generally have a positive transition experience.

Nevertheless, students commonly encounter a number of major challenges, including issues around managing school work and homework, and bullying. The study found several factors contribute to successful transition. These include the provision of assistance to help students become familiar with and manage their physical environment, building positive relationships with teachers, and having extra support from special needs staff. The study suggests there are some simple and practical steps that schools can take to enhance outcomes for successful transition experiences.
\end{abstract}

Keywords: Transition, Autism Spectrum Disorder, Intellectual Disability; Secondary School 


\section{Introduction}

Educational transitions, by their nature, are complex and multifaceted processes (Akos and Galassi 2004). In this paper transition refers to the movement of students from primary school (Years K-6) to secondary school (Years 7-12). In recent years, there has been a growing focus on the importance of effective transition programs for students moving between primary and secondary school (Strnadová and Cumming 2014; Jindal-Snape and Miller 2008; Maras and Aveling 2006; Vinson 2006). In New South Wales (NSW), Australia, where this study was conducted, there is a requirement for schools to develop appropriate transition programs for students with and without disabilities moving between settings (NSW DET 2006).

There are several models in place in Australian schools for all students for the transition process. They range from brief orientation sessions prior to the transition through to specifically designed programs that run over a term, semester or entire year (Marston 2008; Vinson 2006). However, there is no legislation, at state or Commonwealth level, requiring education authorities to provide Individual Transition Plans for students with intellectual disability (O’Neil, Strnadová, and Cumming 2016).

\footnotetext{
Although diverse, successful programs have been recognised as having some common characteristics. These characteristics include; the provision of group and interactive learning options; limiting the number of teachers that students work with by having teachers teach across multiple subjects; and the provision of resources to support students across all domains, including the provision of pastoral support (NSW DET 2006).
} 
Educational transitions for students with intellectual disability involve an added layer of complexity (Hebron 2017; Vinson 2006). Current research has identified several factors that contribute to successful transition for students with disability (Tso and Strnadová 2017; Deacy, Jennings, and O'Halloran 2015; Cremin, Healy, and Gordon 2017). First, the positive impact of parents and teachers working together is widely recognised (Ankeny, Wilkins, and Spain, 2009; Carter, Clark and Kennedy 2005; Maras and Aveling 2006). When planning programs for students with intellectual disability, family involvement is recognised as an important factor in building the confidence and trust of children (Neal and Frederickson 2016; NSW DET 2008; Vinson 2006). Second, the importance of supportive and inclusive teachers and support staff, both during and after transition, is well-documented (Dann 2011; Knesting, Hokansen, and Waldron 2008; Lightfoot and Bond 2013). A positive attitude from teachers, and the use of appropriate pedagogical approaches, is critical to the success of inclusive programs (Beamish, Meadows and Davies, 2010). Despite progress in this area, education authorities and school administrators acknowledge that there remain opportunities for improvement in the transition of students with disability to secondary school (Dockett et al. 2006; Vinson 2006). Parents also state that, in many cases, their expectations surrounding transition are not being met (Jindal-Snape et al. 2006).

This study seeks to contribute to knowledge of processes that can facilitate the successful transition of students with intellectual disability, through examining transition from the perspective of the students that experience it. Research into transition has provided valuable insights into the process for students with intellectual disability, however there are currently only a small number of studies that consider this process from the perspective of students. For example, Dann (2011) examined the transition experiences of 6 students from the south east of England with Autism Spectrum Disorder (ASD), interviewing students, parents and 
school staff. Themes that emerged included the importance of the student-teacher relationship, and the importance of students knowing and feeling comfortable in their physical environment. Students were both excited and anxious about the prospect of transition, but five of the six students went on to experience at least one incident of bullying at secondary school. Interestingly, the study found that students often had a different view of the transition process to that of the adults around them, highlighting the importance of examining the student perspective (Dann 2011).

Neal and Frederickson (2016) also examined how 6 students with ASD in the UK experienced the transition to mainstream secondary schools. Participants reflected on their experiences before and after transition. Most experienced excitement at the prospect of transition, while all also experienced some anxiety. Most expressed positive views about their secondary schools, valuing new friendships and positive relationships with teachers. Students valued the practical information and advice they received about their transition, including things such as visits to their new school. They also valued positive approaches to the change, such as support from family and friends, and positive classroom discussions. Students discussed a number of unnecessary barriers that made transition more difficult. They included strategies such as increasing homework in Year Six in anticipation of increased homework at secondary school. They also did not find it helpful when classroom discussions about transition were focused on negative aspects of the process. Overall, a clear theme emerged of the need for individualised support to best assist students (Neal and Frederickson, 2015). Jindal-Snape et al. (2006) explored the transition process from the perspective of five male students with ASD in Scotland, transitioning from primary to secondary school. They found that delays in transition and interrupted transitions were common, causing stress to students. Nevertheless, these students appreciated the transition programs offered and were 
Knesting et al. (2008) examined the experiences of nine students with mild intellectual disability, transitioning from primary to middle school in the US Midwest. The study revealed that students felt anxious about navigating their physical environment and took an extended period to gain mastery in this domain. Interestingly, the researchers identified a correlation between student input into decisions, and positive outcomes for the student and school (Knesting et al. 2008). Finally, Maras and Avelings' (2006) highly cited research undertook a study involving six students with intellectual disabilities in the UK transitioning from primary to secondary school. Transition programs that enabled students to spend time in their new school prior to formal commencement were identified as beneficial, with longer and/or repeated visits favoured by students. Nevertheless, these students still experienced significant stressors during the transition, including adjusting to the new physical environment, the more challenging academic environment, and longer school hours (Maras and Aveling 2006). Collectively, these studies offer valuable insight into student experiences of transition. The limited number of studies, and the small numbers of students involved in each study, suggest the need for further research in this field.

This research is underpinned by the theoretical construct of 'Student Voice'. A growing body of research highlights the positive and powerful outcomes of providing students with 
the opportunity to be meaningfully consulted about their experiences of learning and teaching (Demetriou and Wilson 2010; Fielding 2004; Flutter and Ruddock 2004; Mitra 2009.) This approach has obvious benefits in special education, as it allows students to be participants in decisions affecting their future. Student Voice also recognises the rights of all children to express a view in decisions that affect them, as enunciated in the United Nations Convention on the Rights of the Child (United Nations 1989). Moreover, as Bergmark and Kostenius (2009) argue, listening to students' experiences and inviting active participation in the research process can lead to measurable advances in student improvement. The lack of active student involvement in transition planning for students with intellectual disability is a serious concern that has been recognised in previous research (Rodriguez, Cumming, and Strnadová 2017; Lightfoot and Bond 2013). The call for stronger student voice is also supported by Kohler's taxonomy of transition intervention services (Kohler and Field 2003). This taxonomy posits five substantive factors that can enhance the transition of students with disabilities. These substantive factors are student-focused planning (which includes student voice), student development, interagency and interdisciplinary planning, family involvement, and program structure (Strnadová and Cumming. 2016). Providing students with a voice throughout their transition was thus a fundamental principle in this research. This research is also theoretically informed by the Ecological Development Model proposed by Bronfenbrenner (1979, 1986, 2005).

This model was utilised to understand the different systems that form the context for the children who are the focus of the current study. The design of the study drew on the "personcontext interrelatedness" (Tudge, et al. 2009, 199) of Bronfenbrenner's systems and their context for the child with a learning disability. The study then sought to understand the participants' interactions with the microsystem (teachers), the mesosystem (support staff), the 
exosystem (teacher education), the macrosystem (education policies), and the chronosystem (the transition from primary to secondary schooling).

The purpose of this study was to provide insight into how ten students with mild to moderate intellectual disability experienced the transition process from mainstream primary schools to secondary schools. This study sought to contribute new knowledge surrounding the student experience of transition, and identify opportunities to improve that experience, through posing the following research questions:

1 How do students with intellectual disability transferring from primary school experience the transition to secondary school?

2 What are the major issues that students with intellectual disability experience during the transition process?

3 What are the factors that students with intellectual disability perceive contribute to their successful transition from primary school to secondary school?

\section{Method}

\section{Research Design}

This research utilised a multiple case study, mixed methods, two-phase design. A multiple case study approach, as Stake (2006) and Yin (1984) state, provides compelling evidence that is sourced from a broad range of participants, contributing to robust findings. The study is located within an interpretive methodological framework, drawing on observations, fieldnotes, semi-structured interviews and the behaviour of participants to capture meaning and 
gain insight. The interpretive paradigm allows the researchers to develop an understanding of the world of the students and to make meaning of their words and actions (Walter 2006). The researchers utilised an approach of narrative inquiry. This enabled the researchers and participants to maintain equal status while relating their stories, allowing the expertise to reside in the participants as much as in the researchers (Atkins and Wallace 2012; Miles and Huberman 1994). The findings reported herein represent one component of a larger study, that explored the perspective of students, parents, teachers and principals about the transition process. This provided the opportunity to utilise member checks, triangulation, persistent observation and progressive subjectivity to confirm the integrity of the data. Before commencing with data collection, approval for this research was obtained from the UOW Ethics Committee and the Catholic Education Office in the Diocese of Wollongong.

\section{Participants}

Participants were ten students from four Catholic primary schools, who transitioned to three Catholic high schools and a Catholic K-12 special school, all located in southwestern Sydney. Students selected for the study were identified with the support of the Catholic Education Office in the Diocese of Wollongong. The southwestern region of Sydney was selected as the area for the study as there were predictable transition patterns for students with intellectual disability moving from primary to secondary schools in this region. The criteria for selection of participants included: students who had a diagnosed intellectual disability; students in their final year of primary school and students who had indicated an intention to attend a Catholic high school in the region.

Of the ten students involved in the study six were boys and four were girls, with four of the students diagnosed with a moderate intellectual disability and six of the students diagnosed 
with a mild intellectual disability. Five of the students in the study were diagnosed with an Autism Spectrum Disorder (ASD) and, as such, had particular learning and social needs. The students entered the study aged between 11 and 12 years and completed the study at 12 to 13 years. Pseudonyms have been used for all students in this paper.

Student details are found in Table 1 below:

Insert Table 1 About here

\section{Data Collection}

Phase One of the data collection process involved observation and semi-structured interviews with the ten students as they completed second semester of year six, just prior to their transition to high school. All interviews and observations were conducted by the lead author. Visits to each of the schools were undertaken in the early stages of the study, in order to establish trust and build relationships with participants and other members of the school communities. During Phase One, there were two formal observations in each classroom, each of one-hour duration. Observations were also carried out in playgrounds, and during interactions with parents. Students then took part in a semi-structured interview, towards the end of year six. When conducting research with children, Greig, Taylor, and MacKay (2007) argue that semi-structured interviews are an effective method of obtaining the children's own perspectives. The interactive and free-flowing nature of this style of interview allows the researcher to access information not necessarily available using other methods of data collection. Interview questions and information sheets were modified to make them accessible to students by simplifying language and using visuals where required. 
The format allowed students to access information and provided them opportunities to raise issues of concern, without being constrained by the need to answer prescribed questions or stay on topic. Interviews during this phase lasted between 20 and 40 minutes, depending upon the interest and capacity of the students. Sample questions included: 'What do you like best about attending school?' 'What do you think will be the best thing about going to high school?' and 'Do you think you will have the same friends in high school as you have in primary school? Why/why not?'

Phase Two involved observation of students in their new high school environments, and a second semi-structured interview. Formal classroom observations were not conducted in secondary schools, as the special education coordinators believed that students would be uncomfortable with observations in the presence of mainstream peers. The students confirmed this as they cited embarrassment as a factor in being publicly observed. Therefore, in this environment the researchers relied upon informal observations, which involved meeting students in the playground, observing their interactions with teachers and peers, and observing their interactions with their parents. The second interview with students took place at the end of their first semester of year seven. Interviews during this phase were of a similar length to those in Phase One. With minor modifications to allow for the changed context, interview questions were kept the same for each phase of the study.

\section{Data Analysis}

The Ecological Development Model proposed by Bronfenbrenner $(1979,1986,2005)$

indicates that the focus in the transition process should be on enhancing the relationships between the child's present environments and the environments they will be moving into. The strength of Bronfenbrenner's model is that it provides a means of examining the various 
transitions throughout a child's development and putting strategies in place to develop skills that have the potential to make the move to a new microsystem smoother and less stressful. (Strnadová and Cumming 2016). As such it was important that there were clear connections between the various microsystems. By involving students, parents, teachers and school principals in each phase of the study the researchers were able to make explicit the various environments the students were operating in. Similarly, the opportunity to observe students and collect data in a variety of settings provided opportunities to observe relationships and the ways students interacted in different environments.

Data analysis was commenced early in the research and strategies for data collection were able to be adjusted to respond to emerging ideas and to strengthen interpretations and findings. As this was a qualitative study, it was important to search for general relationships to build coherent interpretation of the data. Therefore, triangulation, member checks, persistent observation and progressive subjectivity were used as means of maintaining the integrity of the data. The need for a critical friend emerged as a result of the pilot study and proved to be a valuable measure as it provided an objective voice that was able to challenge perceptions and put forward other interpretations of the data. The critical friend was also of assistance in determining codes for mapping the data from observations and interviews and reflecting on the recommendations and reflections that were identified from transcripts and the researcher's perceptions

Data were collected from the observations using observation grids and fieldnotes. Interviews were audio recorded and transcribed. Transcripts were colour coded to highlight important points and issues that were beginning to emerge. For example, the themes that emerged in student interviews during phase one were coded as shown in Table 2. 
Insert Table 2 about here

Coding is recognised as a key process of data analysis (Krathwohl 1998; Mertens 2005; Miles and Huberman 1994; Strauss 1987) and as such, codes were created and, as themes were identified, they were categorised. This allowed data to be organised into areas of similarity, points of difference, and emergent themes. All coding was done by the lead author, and independently reviewed by the second author. Any divergence in coding was resolved through discussion until agreement was reached.

The result was a series of tables, identifying the issues and perspectives of the students. Triangulation was used to support and strengthen interpretations and conclusions in the study (Kervin et al. 2006; Mertens 2005; Stake 1995). Using observations, case notes and transcripts from interviews, convergence of data to support the research findings was demonstrated.

\section{Results}

\section{Phase One}

Primary School Experiences

Establishing student perceptions of primary school formed an important component of Phase One of the study, providing a baseline from which to assess the transition experience.

Overall, students were positive about primary school, and described being happy there. Eight out of ten students described positive experiences of primary school and enjoying grade six; conversely one student expressed that he was glad to leave due to issues with bullying. 
For students, their relationships with teachers were a strong positive feature of their primary school experience. All students were positive about their teachers, and most used words such as kind, helpful, happy and friendly to describe their teachers. For example, Jenny commented about her teacher: 'She is fun and she has always got a smile on her face and when I make fun of her or play with her in the classroom she doesn't get mad at me.' For John, his teachers 'are more patient when I have a hard time. They help me understand and they know exactly what's going on.' Several students made mention of humour and indicated this trait was a positive quality in student-teacher relationships. Janet, for example, commented: 'She is really funny, and she tries to help all the kids as much as she can.'

Friendships were another aspect of primary school about which students felt positive. Typically, students made comments about their friendships such as:

\footnotetext{
I like my class cause it's all open. I can see my friends more even from other classes, so we can see each other in the playground and see each other in the classroom because it's more open learning and I like my teachers. It is much better.
}

Most students (8/10) felt confident that they would stay in touch with their old friends, or make new friends, when they moved to high school. Most students (8/10) also felt comfortable about making new friends. For some students, the opportunity to make new friends was something they were looking forward to at high school. Annie, for example, commented that 'The best thing about leaving [primary school] is more friends.' Some students, however, felt worried about making new friends or losing contact with old friends. 
Students expressed mixed feelings about leaving primary school, from missing friends and teachers, through to being excited about starting at a new school. Paul, for example, commented, 'My feelings about leaving primary school, umm, a bit sad, umm, missing my friends and missing my teachers.' Students expressed a desire to return to visit their schools, such as 'I will visit the teachers and staff and visit the children because I have two buddies, one in Kinder and one in Year 1.' A few students could not comprehend leaving primary school, and had trouble answering this question.

\section{Anticipation of High School}

Students were excited when speaking about high school. They also expressed nervousness about some aspects of going to a new school. Janet remarked: 'I'm excited and a bit nervous. Well it's like a whole new school, like you get to meet lots of different people.' Similarly, Jimmy commented: 'I am nervous about going to high school but it's good for me because I will learn lots more.' Students expressed anxiety about specific issues, including workloads, getting lost, catching the bus, and being bullied. Carly, for example, commented: 'It's bigger, I'll probably get lost and I'll be catching the bus. That's freaky because I've never caught the bus in my life by myself.' The three students transitioning to the Special School did not express the same level of anxiety as that of the students moving to high schools. Their comments indicated they felt comfortable with the transition, such as Brian's remark: 'I'm happy because I am going to a different school next year. The hardest thing will be the work.'

\section{Transition Programs}

Each of the students involved in the study took part in a transition program while at primary school. The programs offered by the four high schools were all different, offering a range of 
experiences. Regardless of the specific program offered, all students felt that the transition program was helpful, and that they felt more comfortable about their new schools as a result. The following statements provide insight into how students experienced their transition program:

On the transition program, I liked them just helping us with everything. Like in the special needs area they have been showing us how to use the diary and one time they had to tell us a place to find and then we had to see how quickly we could get there. (Carly)

Transition has helped by just showing me where everything is. You do all these sports and there is the library. And they tell you about getting organised and getting stuff ready for the next class. But I'm not sure if it is a continuous day (or you get time) to get to your next lesson. I need to learn that before I go into Year 7. (Jimmy)

First time I went I was worried I was going to get lost but now I'm used to it. I feel good, better than I used to. (Bobby)

\section{Phase Two}

Phase two of the research took place after the students transitioned to high school and had an opportunity to settle into their new environments. Interviews and observations were conducted towards the end of students' first semester in high school.

\section{High School Experiences}

Overall, students were positive about their new high school environments. They discussed new friends, the variety of subjects available, the opportunity to work with a number of 
different teachers and their greater independence as highlights. Students made comments about their high school experiences such as:

The best things about high school are you have more friends, you meet new people, you have more teachers than normal and that's really it. (Carly)

You don't have to sit around in one classroom anymore; you get to go to six different classes with six different teachers. (Bobby)

I think being more relaxed, making new friends, meeting new teachers and joining fun activities. (Jimmy)

\section{Teachers}

Students stated that they were happy with their high school teachers and found them helpful and easy to work with. They spoke of teachers providing extra help and assisting with their work outside of regular class time. Students spoke of the special needs staff as being helpful and they discussed the support they received, stating that they were the staff who would seek them out to talk to them. Positive teacher-student relationships emerged as a critical factor in students' experiences of high school. Students also spoke of occasional negative experiences, when teachers yelled or became angry, and many (6/10) expressed strong reactions to these events. Typical comments about teachers included:

\footnotetext{
"The teachers, well they all give me extra help ... yeah." (Bobby)
}

"I like the teachers because they are all nice to me and they're cool." (Jenny) 


\section{Friends}

Students valued the importance of friendships, and most (8/10) stated that it had been easy to make new friends at high school. Two students indicated they were having difficulty making new friends, with being shy proving a barrier to building new friendships. Students also continued to maintain their friendships from primary school (8/10). Most students appeared to be happy socially in their new environment, making comments such as:

I've got heaps more friends here. More than at the other school. (Brian)

And, like, I've got more friends. I mix well with everyone. (Annie)

For some of the boys, however, bullying emerged as an issue. Comments about bullying included:

Bullying, hmm ... well we muck around a lot but it's actually quite serious. I went close to getting into a fight. Really close! (John)

Um I just get bullied around here. Yeah I'm getting bullied by nearly every grade. (Bobby)

Some of the Year $10 \mathrm{~s}$ and $12 \mathrm{~s}$ are not really good blokes and they start to push you around a bit. (John) 


\section{Academic Work}

Students enjoyed the opportunity to learn different subjects each day, and the variety of subjects on offer at secondary school. All students preferred practical subjects, such as Art, Technology, Cooking and Music. Conversely, most students (9/10) expressed a dislike for Maths, indicating it was their least preferred subject. Students made comments such as:

Favourite subjects ... probably still Art ... not Maths, I hate Maths. (Annie)

I like Technology and Art ... they're more hands on. (Andrew, 13)

I like Music because me and my friend Taylah were talking about making a band and we can play instruments and sing. (Jenny)

Homework was an area of concern for the majority of students (7/10), and for all of the students in mainstream high schools. This concern was expressed despite special education coordinators scheduling homework tasks. Comments included:

Maths is hard, and you get like a lot of homework. Yeah and sometimes with Maths like, you can get it, but like you might go over it and just forget it. (Janet)

I get a bit stressed with homework and assessments. I can really stress about assessments. (Jimmy)

Sometimes you get masses of homework and you just can't do it. (Andrew) 


\section{Reflections on Transitioning from Primary School to High School}

Overall, most students stated they were satisfied with their introduction to high school.

Students were enjoying new friendships and the wider variety of subjects on offer. They

liked having more independence and being part of a larger school environment. The majority of students (7/10) expressed that, given the choice, they would rather be in high school than primary school. They nevertheless missed some aspects of their primary schooling, such as the relationships they had with teachers and students, and the smaller environment.

Nonetheless, when asked which school they preferred, the majority $(8 / 10)$ nominated secondary school. Students recognised that it was time to move on, and they enjoyed the many positive aspects of their new environments.

\section{Discussion}

Transitioning from primary school to secondary school is an important milestone in students' education. For students with intellectual disability, it can be a time of both excitement and apprehension. Students want to embrace the new opportunities associated with the secondary school environment, but commonly encounter significant challenges in doing so. To date, much of the research on the transition experience has focused on the perspectives provided by parents, teachers, support staff and principals. Relatively few studies have placed the student experience at the forefront of the research. This study sought to address this imbalance, thereby making a valuable contribution to knowledge about student experiences of transition.

\section{The study was strongly influenced by Bronfenbrenner's ecological development model} $(1979,1986)$ which provided a framework to focus on the transition process as a means of enhancing the interrelationships between each of the students' primary schools and the 
secondary schools that they moved into. This model was particularly relevant as it makes clear the importance of focusing on environments where few interrelationships exist. The relationships between families and secondary schools and between primary and secondary schools were reviewed and strategies that enhanced communication and interrelationships between these settings began to emerge from the data.

The data indicated that transition was a positive experience for most students, and they made a successful start to secondary school. Students experienced a range of transition programs, but all were appreciative of the opportunity to visit and become familiar with their new schools, and to meet staff and students there. The literature indicates that this is not always so, as transition programs can leave students with disability feeling unhappy with their academic prospects and socially isolated (Ankeny et al. 2009; Beamish et al. 2010; Carter et al. 2005; Saggers, Hwang, and Mercer 2011). In this study, students particularly appreciated the opportunity to learn how to navigate the larger school campuses during the transition programs. Students also had mostly positive social experiences during the transition period. They indicated that they were happy and had made new friends. The wider scholarship, however, indicates that this can be problematic. Social transitions can be difficult and can influence student attitudes to secondary school (Carter et al. 2005; Jindal-Snape and Miller 2008). The students struggled with workload and the increasing difficulty of work as the first semester progressed. This is consistent with findings in the literature that identify workload as a problem for all students moving to secondary school (Akos and Galassi 2004; Cauley and Jovanovich 2006; Vinson 2006).

Student voice is increasingly being recognised as a potential means of improving both student outcomes and school structures (Bergmark and Kostenius, 2009). Processes have been 
developed to seek the opinions of students in decisions about their education and welfare (Demetriou and Wilson, 2010), resulting in student voice as a strategy and as a theoretical construct gaining a level of acceptance. Student participants in this study were supported to discuss major issues they experienced during the transition process. Bullying was a significant issue for the boys in the study and they mentioned this on a regular basis. This was despite all schools all having robust anti-bullying policies. This is an area of concern in this study and more broadly as the scholarship is clear that bullying presents a very real barrier to successful transition (Cauley and Jovanovich 2006; Jindal-Snape and Miller 2008).

Homework was raised as an area of concern by students and the need for support in this area was clear. This issue is identified in a number of studies ( $\mathrm{xxxx}$ and $\mathrm{xxxx}, \mathrm{xxxx}$; Lightfoot and Bond,2013; Jindal-Snape et al. 2006; Maras and Aveling 2006). Students also expressed a strong dislike for maths, and significant concerns about their ability to perform to the required standard in maths. These concerns provide clear direction for secondary schools in addressing changes to current practice to improve the experiences of students in the transition period (Ashton 2008; Jindal-Snape and Foggie 2008; Knesting et al. 2008).

Students in this study identified several factors they perceived as contributing to their successful transition from primary school to secondary school. These included initiatives that helped them to manage the physical environment. Strategies and activities that helped students find their way around the secondary school campus, supported them with organisational issues and helped them to get to class on time were highlighted as being helpful in orienting students to their new schools. These findings are supported by research that highlights the importance of addressing the needs of students with disability in the physical domain as a matter of priority (Marston 2008; Vinson 2006). 
Students also identified positive relationships with teachers and friends as a key element of their transitions. Relationship-building is a critical factor in transition. The literature is clear on the importance of having teachers who are positive working with students if they are to transition smoothly into their new schools, with teacher attitude identified as an important factor in the success of transition (Fields 2006; Hsien 2006). Students quickly identified teachers they had positive relationships with, and conversely those with whom they lacked a connection. For example, Janet described good teachers as being 'nice and kind' while Annie described other teachers as 'mean'. The literature is unequivocal in stating that the key to inclusive education and to positive transitions lies in teacher training that focuses on appropriate pedagogical approaches and building positive teacher attitude (Beamish et al. 2010).

\section{Recommendations for Future Practice}

The following recommendations are offered as a means of more effectively supporting students with intellectual disability transitioning from primary to secondary education:

1. Students be provided with opportunities to have input into their own transition plans. This may include opportunities to be part of transition teams, to be involved in student focus groups, and to provide feedback on the success of the programs.

2. Transition programs include a strong focus on helping students learn to navigate the physical environment, recognizing that students with intellectual disability may need additional support to master larger secondary school campuses. 
3. Greater attention is given to the issue of bullying, and how it can be more robustly addressed, particularly for boys.

\begin{abstract}
4. Additional support be provided to aid students to manage their homework, including differentiated homework tasks as necessary.
\end{abstract}

\begin{abstract}
5. A review of the requirements of the maths curriculum be conducted, with a focus on how the curriculum can be made more accessible for students with intellectual disability. Greater differentiation within the curriculum and individualised expectations for achievement may facilitate making maths a less stressful component of school for students in the transition period.
\end{abstract}

6. Schools continue to focus on building positive teacher attitudes and fostering inclusive educational approaches in the classroom.

\title{
Limitations of the Study
}

While important implications can be drawn from the findings, there were limitations to this study. This study was limited to Catholic schools in the southwest region of Sydney, NSW, and as such, there were already established links between the primary and secondary schools involved in the study. The particular ethos of each of the schools in this study supports the inclusion of students with intellectual disability as a core part of their mission, and this may not be typical of all schools. A second limitation is that at the time of the study, the lead author was the principal of the special school involved and was in regular contact with principals and teaching staff at each of the schools involved. The position of the researcher may have influenced the interpretation of the results, although every care was taken in 
conducting member checks with all participants to ensure interview transcripts accurately reflected their views and opinions. A third limitation of the study was its scope and duration. While a reasonable number of participants were included, the number of participants did limit its scope, and the period of follow-up with students was limited to their first semester of secondary schooling.

\section{Conclusion}

This study of the transition experiences of students with mild to moderate intellectual disability has provided valuable insights into the lived experiences of students as they move through the education system. The study highlights the value of giving these students a voice, and an opportunity to have input into their own pathway through the school system. The study has also highlighted several opportunities for schools to improve the way they approach and manage the transition experience for students with intellectual disability. Further research, and innovation, is warranted to ensure successful transition experiences for all students.

\section{References}

Akos, P. and J. Galassi. 2004. "Middle and High School Transitions as Viewed by Students, Parents and Teachers.” Professional School Counselling 7 (4): 212-221.

Ankeny, E., J. Wilkins and J. Spain. 2009. “Mothers' Experiences of Transition Planning for their Children with Disabilities." Teaching Exceptional Children 41 (6): 28-36.

Ashton, R. (2008). "Improving the transfer to secondary school: How every child's voice can matter." Support for Learning 23 (4), 176-182. 
Atkins, L. and S. Wallace. 2012. Qualitative Research in Education. London: Sage.

Beamish, W., D. Meadows and M. Davies. 2010. "Benchmarking Teacher Practice in Queensland Transition Programs for Youth with Intellectual Disability and Autism.” The Journal of Special Education 45 (4): 227-241.

Bergmark U., and C. Kostenius. 2009. ““'Listen to Me When I Have Something to Say’: Students' Participation in Research for Sustainable School Improvement.” Improving Schools 12 (3): 249-260.

Bronfenbrenner, U. 1979. The Ecology of Human Development: Experiments by Nature and Design. Cambridge, MA: Harvard University Press.

Bronfenbrenner, U. 1986. "Ecology of the Family as a Context for Human Development." Research Perspectives Developmental Psychology 22 (6): 723-742.

Bronfenbrenner, U., ed. 2005. Making Human Beings Human: Bio-ecological Perspectives on Human Development. Thousand Oaks, CA: SAGE.

Carter, E., N. Clark, and C. Kennedy. 2005. "Moving from Elementary to Middle School: Supporting a Smooth Transition for Students with Severe Disabilities.” Teaching Exceptional Children 37 (3): 8-14.

Cauley, K. and D. Jovanovich. 2006. "Developing and Effective Transition Program for Students Entering Middle School or High School.” The Clearing House 80 (1): 15-25. 
Cremin, K., O. Healy, and M. Gordon. 2017. "Parental Perceptions on the Transition to Secondary School for their Child with Autism." Advances in Autism 3 (2): 87-99.

Dann, R. 2011. “Secondary Transition Experiences for Pupils with Autistic Spectrum Conditions." Educational Psychology in Practice 27 (3): 293-312.

Deacy, E., F. Jennings, and A. O’Halloran. 2015. “Transition of Students with Autism Spectrum Disorders from Primary to Post-Primary School: A Framework for Success.” Support for Learning 30 (4): 292-304.

Demetriou, H. and E. Wilson. 2010. "Children Should be Seen and Heard: The Power of Student Voice in Sustaining New Teachers.” Improving Schools 13 (1): 54-69.

XXXX., and XXXX. XXXX. (Name deleted to maintain the integrity of the review process)

Dockett, S., B. Perry, D. Whitton, M. Vickers, and J. Johnston. 2006. Sydney Region Transition Project. Sydney: NSW Department of Education and Training.

Fielding, M. 2004. “Transformative Approaches to Student Voice: Theoretical Underpinnings, Recalcitrant Realities.” British Educational Research Journal 30 (2): 295311

Fields, B. 2006. "Beyond Disabilities: Broadening the View of Special Needs and the Inclusive Education Challenges Facing Primary Teachers." Paper presented at the Australian 
Association for Research in Education Annual Conference: Engaging Pedagogies, Adelaide, November 27-30.

Flutter, J. and J. Ruddock. 2004. Consulting Pupils: What's in it for Schools? London: Routledge Falmer.

Greig, A., J. Taylor, and T. MacKay. 2007. Doing Research with Children. $2^{\text {nd }}$ ed. Thousand Oaks, CA: Sage.

Hebron, J. 2017. “The Transition from Primary to Secondary School for Students with Autism Spectrum Conditions." In Supporting Social Inclusion for Students with Autism Spectrum Disorders: Insights from Research and Practice, edited by C. Little, 84-99. London: Taylor and Francis.

Hsien, M. 2007. “Teacher Attitudes Towards Preparation for Inclusion - In Support of a Unified Teacher Preparation Program.” Postgraduate Journal of Education Research 8 (1): 49-60.

Jindal-Snape D., W. Douglas, K. Topping, C. Kerr, and E. Smith. 2006. “Autism Spectrum Disorders and Primary-secondary Transition." International Journal of Special Education 21 (2): $18-31$.

Jindal-Snape, D. and J. Foggie. 2008. “A Holistic Approach to Primary-high School Transitions.” Improving Schools 11 (1): 5-18. 
Jindal-Snape, D., and D. Miller. 2008. “A Challenge of Living? Understanding the Psychosocial Processes of the Child during Primary-high School Transition through Resilience and Self-esteem Theories.” Educational Psychology Review 20 (3): 217-236.

Kohler, P. D., and S. Field 2003.’Transition-focused education: Foundation for the future.” The Journal of Special Education, 37(3), 174-183.

Kervin, L., W. Vialle, J. Herrington and T. Okely. 2006. Research for Educators. Melbourne: Cengage Learning.

Knesting, K., C. Hokanson, and N. Waldron, N. 2008. "Settling In: Facilitating the Transition to an Inclusive Middle School for Students with Mild Disabilities." International Journal of Disability, Development and Education 55 (3): 265-276.

Krathwohl, D. 1998. Methods of Educational and Social Science Research: An Integrated Approach (2nd ed.). New York: Addison Wesley Educational.

Lightfoot, L. and C. Bond. 2013. “An exploration of primary to secondary school transition planning for children with Down's syndrome." Educational Psychology in Practice, 29, (2): 163-179, http://dx.doi.org/10.1080/02667363.2013.800024

Maras, P. and E. Aveling. 2006. "Students with Special Educational Needs: Transitions from Primary to High School.” British Journal of Special Education 33 (4): 196-203. 
Marston, J. 2008. "Perceptions of Students and Parents Involved in Primary to High School Transition Programs.” Paper presented at Australian Association for Research in Education, International Education Research Conference, Brisbane, 10-12 August.

Mertens, D. 2005. Research and Evaluation in Education and Psychology: Integrating Diversity with Quantitative, Qualitative, and Mixed Methods. Thousand Oaks, CA: SAGE.

Miles, M., and A. Huberman. 1994. Qualitative Data Analysis. 2nd ed. Newbury Park, CA: SAGE.

Mitra, D. 2009. "Strengthening Student Voice Initiatives in High Schools: An Examination of the Supports Needed for School-based Youth-adult Partnerships." Youth and Society 40 (3): $311-335$.

Neal, S. and Frederickson, N. 2016. “ASD Transition to Mainstream Secondary: A Positive Experience?” Educational Psychology in Practice 32 (4): 355-373.

NSW Department of Education and Training. 2006. Our Middle Year Learners - Engaged, Resilient, Successful. An Education Strategy for Years 5-9 in NSW 2006-2009. Sydney: NSW DET.https://www.det.nsw.edu.au/detresources/Our_Middle_Years_gANxIHEeuA.pdf NSW Department of Education and Training. 2008. Who's Going to Teach My Child? A Guide for Parents of Children with Special Learning Needs. Sydney: NSW DET. 
O’Neill, S.C., Strnadová, I., \& Cumming, T. 2016. Evidence - based transition planning practices for secondary students with disabilities: What has Australia signed up for? The Australasian Journal of Special Education, 40(1), 39-58.

Rodriguez, C., T. Cumming, and I. Strnadová. 2017. “Current Practices in Schooling Transitions of Students with Developmental Disabilities." International Journal of Educational Research 83: 1-19. doi: 10.1016/j.ijer.2017.02.006

Saggers, B., Y. Hwang, and K. Mercer. 2011. "Your Voices Count: Listening to High School Students with Autism Spectrum Disorder.” Australian Journal of Special Education 35 (2): 173-190.

Stake, R. 1995. The Art of Case Study Research. Thousand Oaks, CA: SAGE.

Stake, R. 2006. Multiple Case Study Analysis. New York: The Guilford Press.

Strauss, A. 1987. Qualitative Analysis for Social Scientists. Cambridge: Cambridge University Press.

Strnadová, I. and T. Cumming. 2016. Lifespan Transitions and Disability: A Holistic Perspective. London: Routledge

Strnadová, I. and T. Cumming. 2014. "The Importance of Quality Transition Processes for Students with Disabilities across Settings: Learning from the Current Situation in New South Wales. Australian Journal of Education 58(3): 318-336. 
Taylor, C. and C. Robinson. 2009. "Student Voice: Theorising Power and Participation." Pedagogy, Culture and Society 17 (2): 161-175.

Tso, M. and I. Strnadová. 2017. "Students with Autism Transitioning from Primary to Secondary Schools: Parents’ Perspectives and Experiences.” International Journal of Inclusive Education 21 (4): 389-403.

Tudge, J. R. H., Mokrova, I., Hatfield, B. E., \& Karnik, R. B. (2009). “Uses and misuses of Bronfenbrenner's bioecological theory of human development." Journal of Family Theory \& Review 1: 198-210.

United Nations. 1989. Convention on the Rights of the Child.

Vinson, T. 2006. “Good Transitions: Through the Eyes of Primary and High School Principals." Paper presented at Cornerstones Conference, Sydney, September 22-23.

Walter, M. (ed.) (2006). Social Research Methods: An Australian perspective. Melbourne, VIC: Oxford University Press.

Yin, R. 1984. Case Study Research: Design and Methods. Thousand Oaks, CA: SAGE. 
Table 1: Student participant demographic data

\begin{tabular}{|c|c|c|c|c|c|}
\hline Name & Age & $\begin{array}{l}\text { Intellectual } \\
\text { Disability }\end{array}$ & School Setting & $\begin{array}{l}\text { Transitioning } \\
\text { School }\end{array}$ & Support Required \\
\hline John & 11 & $\begin{array}{l}\text { Mild } \\
\text { Intellectual } \\
\text { Disability } \\
\text { ASD }\end{array}$ & $\begin{array}{l}\text { Inclusive Open } \\
\text { Plan }\end{array}$ & $\begin{array}{l}\text { Secondary } \\
\text { School } 3\end{array}$ & $\begin{array}{l}\text { Anger management } \\
\text { support/learning } \\
\text { support }\end{array}$ \\
\hline Jenny & 12 & $\begin{array}{l}\text { Moderate } \\
\text { Intellectual } \\
\text { Disability }\end{array}$ & $\begin{array}{l}\text { Learning Centre } \\
\text { \& Integration }\end{array}$ & $\begin{array}{l}\text { Special } \\
\text { School }\end{array}$ & $\begin{array}{l}\text { Learning } \\
\text { support/social } \\
\text { support }\end{array}$ \\
\hline Brian & 12 & $\begin{array}{l}\text { Moderate } \\
\text { Intellectual } \\
\text { Disability } \\
\text { Di George } \\
\text { Syndrome } \\
\end{array}$ & $\begin{array}{l}\text { Learning Centre } \\
\text { \& Integration }\end{array}$ & $\begin{array}{l}\text { Special } \\
\text { School }\end{array}$ & $\begin{array}{l}\text { Learning } \\
\text { support/social } \\
\text { support }\end{array}$ \\
\hline Carly & 11 & $\begin{array}{l}\text { Mild } \\
\text { Intellectual } \\
\text { Disability }\end{array}$ & $\begin{array}{l}\text { Inclusive } \\
\text { Classroom }\end{array}$ & $\begin{array}{l}\text { Secondary } \\
\text { School } 1\end{array}$ & $\begin{array}{l}\text { Friendship } \\
\text { issues/social } \\
\text { support/learning } \\
\text { support }\end{array}$ \\
\hline Paul & 12 & $\begin{array}{l}\text { Moderate } \\
\text { Intellectual } \\
\text { Disability } \\
\text { ASD }\end{array}$ & $\begin{array}{l}\text { Learning Centre } \\
\text { \& Integration }\end{array}$ & $\begin{array}{l}\text { Special } \\
\text { School }\end{array}$ & $\begin{array}{l}\text { Language support/ } \\
\text { social } \\
\text { support/learning } \\
\text { support }\end{array}$ \\
\hline Annie & 12 & $\begin{array}{l}\text { Mild } \\
\text { Intellectual } \\
\text { Disability }\end{array}$ & $\begin{array}{l}\text { Inclusive Open } \\
\text { Plan }\end{array}$ & $\begin{array}{l}\text { Secondary } \\
\text { School } 1\end{array}$ & $\begin{array}{l}\text { Learning } \\
\text { support/social } \\
\text { support }\end{array}$ \\
\hline Jimmy & 11 & $\begin{array}{l}\text { Moderate } \\
\text { Intellectual } \\
\text { Disability }\end{array}$ & $\begin{array}{l}\text { Inclusive Open } \\
\text { Plan }\end{array}$ & $\begin{array}{l}\text { Secondary } \\
\text { School } 2\end{array}$ & $\begin{array}{l}\text { High anxiety/social } \\
\text { support/stress } \\
\text { management } \\
\text { support/learning } \\
\text { support }\end{array}$ \\
\hline Janet & 12 & $\begin{array}{l}\text { Mild } \\
\text { Intellectual } \\
\text { Disability } \\
\text { ASD }\end{array}$ & $\begin{array}{l}\text { Inclusive Open } \\
\text { Plan }\end{array}$ & $\begin{array}{l}\text { Secondary } \\
\text { School } 1\end{array}$ & Learning support \\
\hline Bobby & 13 & $\begin{array}{l}\text { Mild } \\
\text { Intellectual } \\
\text { Disability } \\
\text { ASD }\end{array}$ & $\begin{array}{l}\text { Inclusive Open } \\
\text { Plan }\end{array}$ & $\begin{array}{l}\text { Secondary } \\
\text { School } 1\end{array}$ & $\begin{array}{l}\text { Social support/stress } \\
\text { management } \\
\text { /learning support }\end{array}$ \\
\hline Andrew & 12 & $\begin{array}{l}\text { Mild } \\
\text { Intellectual } \\
\text { Disability } \\
\text { ASD }\end{array}$ & $\begin{array}{l}\text { Inclusive } \\
\text { Classroom }\end{array}$ & $\begin{array}{l}\text { Secondary } \\
\text { School } 3\end{array}$ & $\begin{array}{l}\text { Learning } \\
\text { support/social } \\
\text { support }\end{array}$ \\
\hline
\end{tabular}


Table 2: Initial coding of themes

\begin{tabular}{|l|l|}
\hline Teachers & what they thought of their teachers/what made a good/bad teacher \\
\hline Favourite places & Places they felt safe/liked to go \\
\hline Subjects & the subjects students liked and disliked \\
\hline Primary school & students discussed primary school/what they liked and disliked \\
\hline Friends & did students think they would make new friends/keep old friends? \\
\hline Possible issues & what did students think would be their biggest issue/problem? \\
\hline Secondary school & how they felt about moving to secondary school \\
\hline
\end{tabular}




\section{Response to Reviewers}

We thank the reviewers for their highly valuable feedback which has allowed the authors to improve the manuscript. The answers to specific comments are provided in the table below. All changes are highlighted in yellow in the Manuscript

\begin{tabular}{|c|c|c|c|}
\hline Reviewer: & Point Raised: & Action in Response: & $\begin{array}{l}\text { Page } \\
\text { Number(s): }\end{array}$ \\
\hline 1 & $\begin{array}{l}\text { Provide a table with } \\
\text { participant } \\
\text { characteristics }\end{array}$ & $\begin{array}{l}\text { Table } 1 \text { Student participant } \\
\text { characteristics has been } \\
\text { added under Participants }\end{array}$ & $\begin{array}{l}\text { Approx } \\
\text { Page } 6\end{array}$ \\
\hline 1 & $\begin{array}{l}\text { The last sentence of the } \\
\text { first paragraph refers to } \\
\text { successful models they } \\
\text { discussed in the } \\
\text { previous sentence Are } \\
\text { the authors referring to } \\
\text { the transition they } \\
\text { discussed in the } \\
\text { previous sentence or } \\
\text { special education } \\
\text { models? }\end{array}$ & $\begin{array}{l}\text { There is a mixture of both } \\
\text { regular and special } \\
\text { education models } \\
\text { We have amended wording } \\
\text { to make this clearer }\end{array}$ & Page $2 n$ \\
\hline 1 & $\begin{array}{l}\text { On page } 4 \text { line } 25 \text { The } \\
\text { sentence that begins } \\
\text { with " They perceived as } \\
\ldots . \text { Is awkward and } \\
\text { should be reworded }\end{array}$ & $\begin{array}{l}\text { This sentence has been } \\
\text { rewritten. Starting with } \\
\text { 'They included strategies' }\end{array}$ & Page 4 \\
\hline 1 & $\begin{array}{l}\text { Ensure that citations } \\
\text { match the reference list. } \\
\text { Check spelling of } \\
\text { Ankene and Fields on } \\
\text { page } 2 \text { NSW DET } \\
\text { check whether it is } 2005 \\
\text { or } 2006 \text {. }\end{array}$ & $\begin{array}{l}\text { All of the citations match } \\
\text { the reference list. } \\
\text { All spelling and } \\
\text { publication dates have } \\
\text { been checked }\end{array}$ & \\
\hline 2 & $\begin{array}{l}\text { The authors use the term } \\
\text { "intellectual disabilities" } \\
\text { "intellectual disability" } \\
\text { choose one or the other }\end{array}$ & $\begin{array}{l}\text { We have chosen } \\
\text { intellectual disability' } \\
\text { throughout the Manuscript }\end{array}$ & \\
\hline 2 & Spelling of references & $\begin{array}{l}\text { All spellings have been } \\
\text { corrected }\end{array}$ & $\begin{array}{l}\text { Page } 2 \text { and } \\
\text { reference }\end{array}$ \\
\hline
\end{tabular}




\begin{tabular}{|c|c|c|c|}
\hline & & & list \\
\hline 2 & $\begin{array}{l}\text { Introduction - It should } \\
\text { be mentioned that there } \\
\text { is no national legislation } \\
\text { which would outline } \\
\text { transition planning for } \\
\text { students with disabilities }\end{array}$ & $\begin{array}{l}\text { Sentence has been added } \\
\text { acknowledging this } \\
\text { Recommended reference } \\
\text { has been included }\end{array}$ & Page 2 \\
\hline 2 & $\begin{array}{l}\text { Some of the references } \\
\text { used in the introduction } \\
\text { are outdated }\end{array}$ & \begin{tabular}{|l} 
References have been \\
updated Older references \\
have been eliminated
\end{tabular} & $\begin{array}{ll}\text { Pages } & 2,3 \\
\text { and } 4\end{array}$ \\
\hline 2 & $\begin{array}{l}\text { On pages 3-4 Please add } \\
\text { information about the } \\
\text { context }\end{array}$ & $\begin{array}{l}\text { Contextual details such as } \\
\text { country, age and number } \\
\text { of participants has been } \\
\text { added }\end{array}$ & $\begin{array}{ll}\text { Pages } & 3 \\
\text { and } 4\end{array}$ \\
\hline 2 & $\begin{array}{l}\text { I would recommend } \\
\text { Mentioning Kohler's } \\
\text { Taxonomy of Transition } \\
\text { Programming } 2.0 \text {. One } \\
\text { of its five pillars is } \\
\text { student involvement } \\
\text { very relevant to this } \\
\text { study }\end{array}$ & $\begin{array}{l}\text { We thank the reviewer for } \\
\text { this suggestions it has been } \\
\text { added }\end{array}$ & Page 6 \\
\hline 2 & $\begin{array}{l}\text { The authors state that } \\
\text { their research was } \\
\text { theoretically informed } \\
\text { by Bronfenbrenner' } \\
\text { model. I would like to } \\
\text { encourage the authors to } \\
\text { elaborate more on how } \\
\text { exactly did they use the } \\
\text { model to inform their } \\
\text { study }\end{array}$ & $\begin{array}{l}\text { A paragraph outlining how } \\
\text { Bronfenbrenner's model } \\
\text { informed the study was } \\
\text { added }\end{array}$ & Page 6 \\
\hline 2 & $\begin{array}{l}\text { I assume that ..... an } \\
\text { easy to read participant } \\
\text { information sheet and } \\
\text { consent form was } \\
\text { developed . Please } \\
\text { mention it in the } \\
\text { manuscript .Also } \\
\text { mention visuals }\end{array}$ & $\begin{array}{l}\text { Sentence has been added } \\
\text { under Data Collection }\end{array}$ & Page 9 \\
\hline 2 & $\begin{array}{l}\text { How did } \\
\text { Bronfenbrenner's model } \\
\text { inform the analysis. }\end{array}$ & $\begin{array}{l}\text { Paragraph has been added } \\
\text { under Data Analysis }\end{array}$ & Page 10 \\
\hline
\end{tabular}




\begin{tabular}{|c|c|c|c|}
\hline 2 & $\begin{array}{l}\text { More detail about the } \\
\text { process of data analysis } \\
\text { is needed }\end{array}$ & $\begin{array}{l}\text { The data analysis section } \\
\text { has been substantially } \\
\text { rewritten and a table } \\
\text { (Table 2) has been added } \\
\text { as per recommendations of } \\
\text { the reviewer }\end{array}$ & $\begin{array}{l}\text { Page } 10,11 \\
\text {, and } 12 .\end{array}$ \\
\hline 2 & $\begin{array}{l}\text { Similar to the } \\
\text { Introduction } \\
\text { recommend updating of } \\
\text { the references }\end{array}$ & $\begin{array}{l}\text { More recent references } \\
\text { have been added and older } \\
\text { references removed }\end{array}$ & $\begin{array}{l}\text { Pages 19- } \\
21\end{array}$ \\
\hline 2 & $\begin{array}{l}\text { I would like to see the } \\
\text { authors discussing the } \\
\text { results from the } \\
\text { framework of Students } \\
\text { Voice and } \\
\text { Bronfenbrenner's model }\end{array}$ & $\begin{array}{l}\text { A paragraph discussing the } \\
\text { results from } \\
\text { Bronfenbrenner's } \\
\text { framework has been added } \\
\text { to page } 19 \\
\text { Another paragraph } \\
\text { discussing the results from } \\
\text { Student Voice framework } \\
\text { has been added to Page } 20\end{array}$ & $\begin{array}{l}\text { Pages 19- } \\
20 .\end{array}$ \\
\hline
\end{tabular}

